\title{
The Mental Virus and Enhancing Immunity through Art 精神病毒及通过艺术增强免疫力
}

\author{
Guo Haiping \\ Nanjing Outsider Art Studio, China
}

\begin{abstract}
This article talks about how words and text are a kind of artificial virus similar to biological viruses. The survival, growth and evolution of this artificial virus and its mechanism of harm to humans are very similar to biological viruses. What is different is how this mental virus threatens people's lives and health is not through the body but through the mind. Regarding mental threat, the author believes that human Self-nature should be fully mobilized to enhance the immunity of human spirit, and art is an ideal way to mobilize human beings' nature of Self. In addition, the author also believes people can also use this kind of mental virus reasonably, so that it can become a mental vaccine to prevent the human mind from being violated.
\end{abstract}

Keywords: mental virus, words, Self, outsider art

\begin{abstract}
摘要
《精神病毒的幻象》是将文字视为一种类似于生物病毒的一种人造病毒，这种人造病毒 的存活、生长和进化方式，以及对人构成伤害的机制与生物病毒都极为相似。有所不同 的是，这种精神病毒威胁人生命健康的不是人的肉体而是人的精神健康。对于精神上的 威胁，作者认为应该充分调动人的自性来增强人精神的免疫能力，而艺术正是调动人自 性的一种理想的方式方法。另外，作者也认为对于这种精神病毒，人们也可以通过合理 的应用，从而使它成为一种预防人精神受到侵害的精神疫苗。
\end{abstract}

关键词 : 精神病毒，文字，自性，原生艺术

At this moment, a new coronavirus (2019-nCoV) named by the World Health Organization (WHO) is spreading all over the world. The attack of this virus is the most serious epidemic encountered by living human beings today. It not only threatens the lives and health of countless people, but also constantly breaks through and challenges what we know in our everyday lives. Faced with such a fierce epidemic, everyone is asking how this virus came to be, what impact it will have on the existing social order of mankind, and how humans should view life and death in this epidemic. Everyone's questioning made me think of the existence of another virus. I called it a mental virus.

Before we understand what mental virus is, let us understand what biological and computer viruses are. From the biomedical point of view, virus is a kind of microbe that does not have a cellular structure. It does, however, have the ability to copy itself and live on. It is like all other living beings, is able to reproduce, mutate, and evolve. It has a very small volume and very simple structure. In addition, it is strongly parasitic, meaning that it is totally depended upon the energy and metabolism of the host for all 
the materials and energy it needs to live. Once it leaves the host cell, the virus is just a large chemical molecule that ceases to function and can be made into a protein crystal that is a nonliving organism. Once encountering a host, the virus would bind to the host, enter, copy, assemble, and reproduce. This is its typical life process. In regards to the origin of the virus, a theory considers it a degradation from bacteria. Because of its high dependency on a host, it has lost the ability to survive without the host.

The computer virus is a code that is inserted into computer programs to destroy the computer functions or data. The computer virus is contagious. It has an incubation period and can be triggered into expression. The life span of the computer virus is composed of development, infection, latency, onset, discovery, digestion, and distinction. The computer virus can stay inside the storage system or program of the computer, waiting for onset when there are sufficient conditions. Through changing the existing programs, the virus copies itself into these programs. As a result, the original programs are infected and malfunctioning.

The mental virus in this article is like the biological virus, possessing the ability to pass on its genetic codes, to mutate, and to evolve. It is also like the computer virus, able to spread, hide, infect, be latent, explode, express, an destroy. The mental virus is the words and languages that human beings have developed. The reason why I see words and languages as mental virus is because they possess the characteristics of biological and computer viruses. Many contemporary thinkers have provided proofs for this conclusion in their research results. For example, psychoanalyst Jacques Lacan is such a thinker. After in depth study of psychoanalytic theory and language, he discovered that the signans of language is like the conscious in Freud's theory and the designatum of language is like the unconscious. The unconscious is not only structural like the language, but is also produced by language. Lacan even thought that spoken language could never express the meaning that it was intended. He suggested that human language was a slip of the tongue and that language was killing objects as well as humans.

Today, treating human-made language as a mental virus may be difficult for most modern civilizations, because the education that everyone has received in the past regards the invention of words as the greatest invention of mankind, just as the word "civilization" contains the meaning of "civil". In this regard, of course, we cannot easily deny the huge benefits brought by words to human beings. However, with the continuous development of human civilization, no one can deny that while civilization has brought countless convenience and wealth to human beings, it has indeed brought humanity more and more "civilized diseases". Faced with these endless "civilized diseases", anthropologists, psychologists, and philosophers began to reflect. They discovered that human beings' past idea of ourselves being the center of this world was obviously too radical. More and more research shows that the presence of humans in the universe is very small and short-lived, and the emergence of a large number of civilized diseases is directly related to human beings' high estimates of our own existence.

Looking back at the history of human development, the threat of words to people's mental health was not recognized in the early days of the construction of words. This is because in the early days, words did not pose a threat to human health. Because during that period, our immune system was strong enough to resist and dispel the negative 
effects that words had on people. But with the nonstop replication, inheritance, mutation and upgrading of words, their erosive effects on the human spirit had gradually begun to show. When humans really began to realize such side effects, we already had dependence on words. At this time, even if human beings wanted to change this situation, we were already powerless to do so. Especially today, when we have developed higher level of intelligence, our dependency becomes more prominent.

How did words develop into a virus that threatened the mental health of people? Lacan told us that when we were exposed to language as children, our language and culture systems have forced the order and structure of language into our brains. When we unwittingly enter into the web of the signifier, we lose our right of way. When words enter the human brain, just as the coronavirus enters the human body, they will devour the human nervous system until they control the human thought, behavior and perception systems. The reason why words can control human thought, behavior, and perception systems is because they are the product of generalization, induction, and abstraction of the world according to human subjective will. The reason why humans want to make such generalizations, inductions, and abstractions is due to the expansion of human desires. Humans want to get rid of the domination and control of nature in this way, so that we can become the masters of this world. But the problem is that, in the beginning humans did not expect that this form they created would have such extraordinary capabilities to replicate and evolve, let alone that humans were the most ideal hosts they need to survive and develop.

Faced with the increasing control of knowledge over people's mind, Carl Jung, another psychoanalyst, had a very deep embodied experience. He wrote in the Red Book, "Save me, don't let me be stifled in my own knowledge. My rich knowledge threatens to push me down. My knowledge is like a troop of thousands of speakers, shouting like a lion's roar, the air is left shuddering, and me defenseless, just like their victim (Jung, 2013)." Fortunately, he later found a way out in the Eastern culture, as he wrote in The Secret of the Golden Flower: The Book of Chinese Life, "Let everything go with nature, do nothing, do whatever you want ... these became the key to successfully opening of the door to Tao (Jung \& Wei, 2016)." And the "key to open the door" that Jung found, in my opinion is also a key for us to unlock the mental immune system. This immune system is the "self" world according to Jung.

Jung proposed that, "Self is the goal of our lives, and it is the most complete manifestation of the destined combination of what we call personality (Jung, 2014)." How can we make our "self" work? After summarizing the experience and lessons from Eastern and Western cultures, Jung found a channel to realize his own "self". This channel is what he called "self-actualization", and Jung said, "Self-actualization is the realization of the law of life. Therefore, the so-called self-actualization is also a natural integration with the laws of the universe. For individual humans, this means that it must be done at the level of consciousness. This consciousness naturally harmonizes with the whole nature, which is also an expression of the concept of Tao (Shen \& Gao, 2018)."

Once we understand about self and self-actualization, the next step involves the issue of implementation. In regards to this, Jung's Student Marie-Louise von Franz said, "Jung saw active imagination as the supreme way of self-actualization (Shen \& Gao, 2018)." Shen Heyong, a Chinese scholar who studies Jung's psychology, said, "In Jung's view, word 
association and analysis of dreams are still methods of indirect communication with the unconscious. Active imagination is a method for direct contact with the unconscious. Many Jungian psychoanalysts call active imagination 'dreaming with eyes open'. In Daryl Sharp's The Jung Lexicon, active imagination is defined as a way to absorb the unconsciousness through self-expression (Shen, 2014)." Jung found a transcendental mechanism in active imagination, which was "a cooperative mechanism between conscious and subconscious factors", and considered imaginary imagery itself to have all the elements he needed for the orderly development and transformation of his spiritual life (Shen, 2016). Before officially using active imagination to represent his main method of psychological analysis, Jung had tried other ways of expression, such as the picture method, transcendent function, active fantasy, technique of introversion, etc. (Shen, 2016).

What makes Jung different from other psychologists and psychiatrists is that he was fully aware that relying on abstract theory alone could not solve our mental problems. In order to break through the limitations of theory, he did in-depth research of the various spiritual practices in the East. At the same time, he also attached great importance to the role of art on the human soul. To this end, he painted a large number of paintings, and these creative practices did indeed bring him many unexpected gains. As he himself said, "With the help of these pictures, I was able to observe my spiritual changes day by day (Feng, 2010)." He talked about the relationship between art and human destiny. He said, "Art transforms our personal destiny into the destiny of all humans. It awakens all those compassionate powers in us. It is these powers that ensure that human beings can escape all dangers and reach the dawn. This is the great mystery of art. It is also the mystery of why art influences us (Jung, 1997)."

The reason why making art can have such an important impact on the spiritual world of people is that art-making is different from words. The relationship between art and people is such that art can express and convey the aspirations of the human soul through colors, lines, and different compositions. People can recognize and understand this expression without analyzing, intellectualizing, and justifying. We only need to rely on our instincts and intuitions to understand. Art here does not mean those that rely on the knowledge and experience of others to complete, but refers to those works that rely on human instinct and nature. The artist can do whatever he/she wants. Only

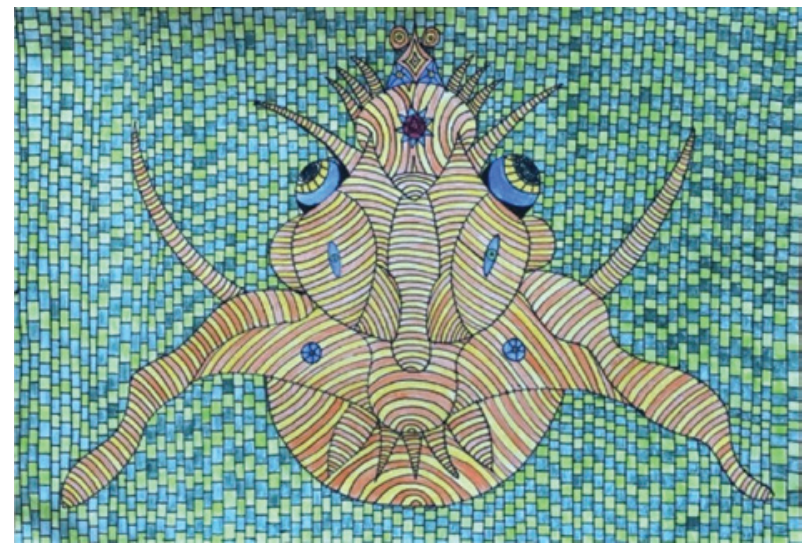



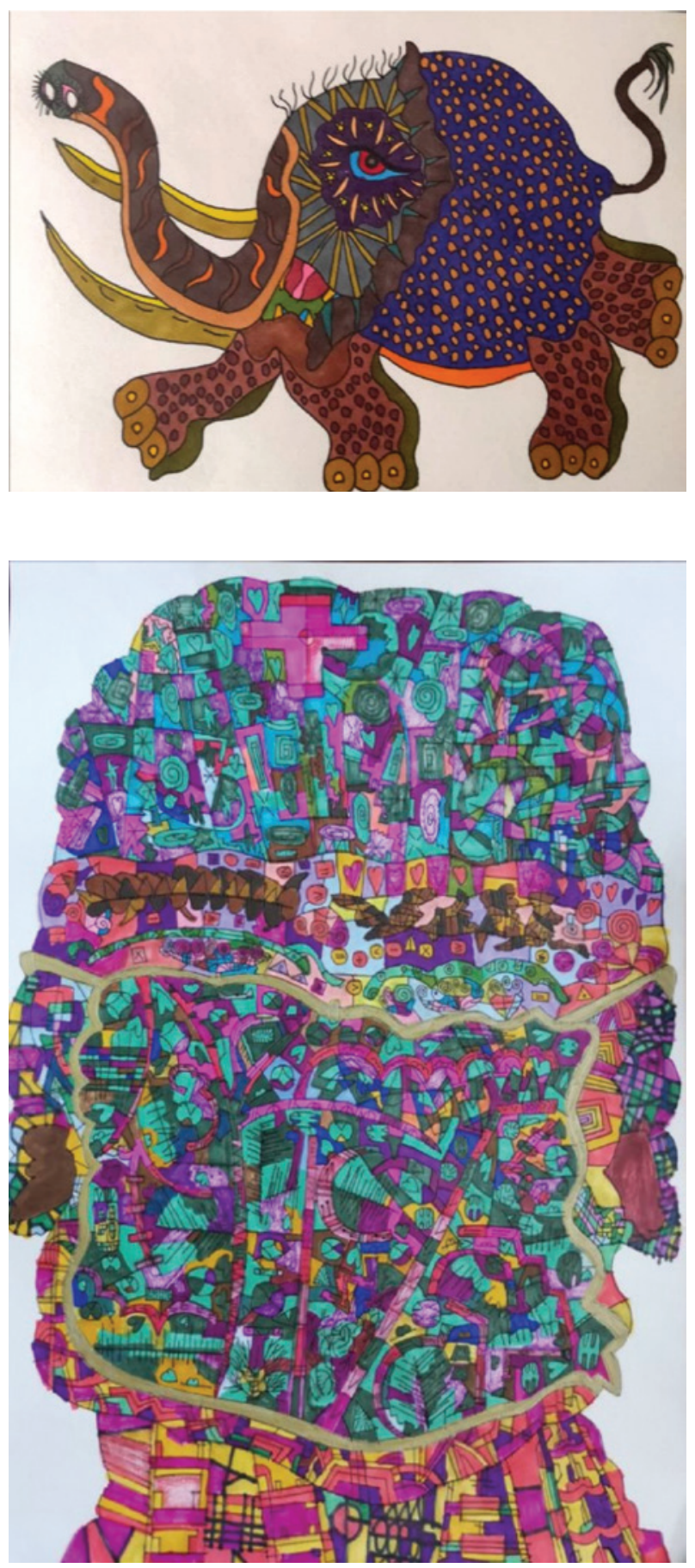

such works are possible to complete the self-actualization mission that Jung had hoped everyone can complete. Because of this, outsider art will be closer to nature and more able to reflect the truth of human life and spiritual world. Words are different. Their 

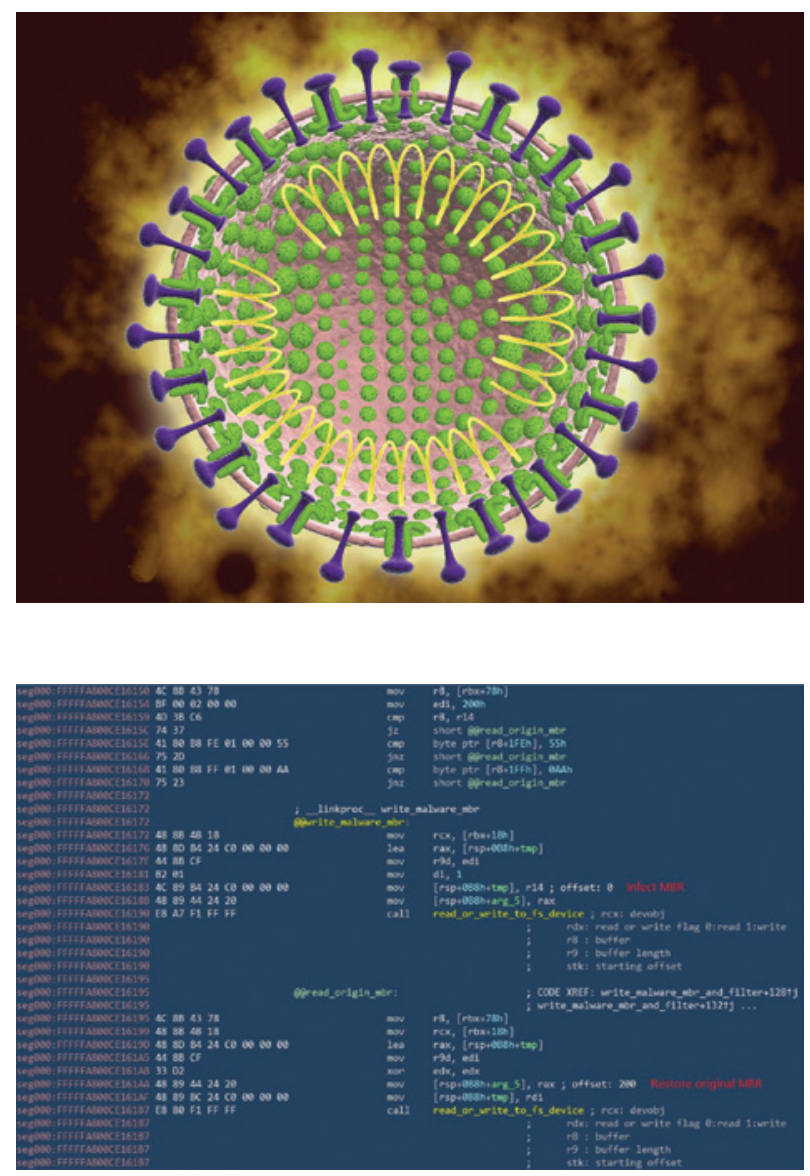

construction was originally a generalization, induction, and abstraction of the world. The meaning that words express can only be the product of the general experience of human beings. Therefore, it is difficult to reflect the differences and contingencies of life in continuous change. And these differences and contingencies are exactly the true manifestation of human soul. Because of this, Jung thought that word association and analysis of dreams are still indirect ways of communication.

Of course, we cannot completely deny the value and significance of words because they are regarded as a mental virus in this article. The purpose of writing this article is only to help everyone see beyond the benefits and conveniences that words bring to humanity, while ignoring their side effects. If these side effects are ignored, words will most likely be transformed into a mental virus that threatens and harms human health. The best way to prevent words from turning into a mental virus is to work hard to improve your mental immunity. If we want to improve our mental immunity, we can only rely on our own consciousness of life. Only when we have some consciousness of our life, we can distinguish knowledge's different kinds of effects on human spirit and make it a truly positive force in perfecting human life. At that time, the initiative of human life will really be in our own hands, which is what Jung called the self-actualization. 


\section{About the Author}

Guo Haiping郭海平. Born in Nanjing in 1962, Guo is a contemporary artist, founder of the Nanjing Outsider Art Studio, founder of Outsider Art Therapy in China, and editor-in-chief of "Outsider Art Series". Guo has published several books including, "Crazy Art: Chinese Mental Patient Art Report", "Chinese Outsider Art Notes", "I'm Sick, Therefore I Am", etc.

\section{References}

Feng, J. (2010). Jung's Active imagination: Four Stages of Formation. CNKI. http://cdmd.cnki.com.cn/ Article/CDMD-10200-2010179207.htm.

Jung, C. G. (1997). The Collected Works of Jung (p. 122). Reform Press.

Jung, C. G. (2014). The Collected Works of Jung (p. 238). Changchun Press.

Jung, C. G. (2013). The Red Book (p. 26). Central Compilation and Translation Press.

Jung, C. G., \& Wei, L. (2016). The Secret of Golden Flower - The Book of Life in China (pp. 25-26). Commercial Press.

Shen, H., \& Gao, L. (2018). Jung and China (p. 219 and 212). Capital Normal University Press.

Shen, H. (2014). Psychoanalysis: Understanding and Experience (p. 148). Sanlian Bookstore.

Shen, H. (2016). Jung's Active Imagination and Methods. Doc 88. http://www.doc88.com/p-0418913165889. html. 